\title{
PECULIARITIES OF CENTRAL AND PERIPHERAL CHANGES AT ONSET OF DOSED AND MAXIMAL EXERCISE TESTS
}

\author{
Birutė Zacharienė, Jonas Poderys, Eugenijus Trinkūnas, Alfonsas Buliuolis \\ Lithuanian Academy of Physical Education, Kaunas, Lithuania
}

\begin{abstract}
Research background and hypothesis. Since varying types of physical workloads activate different physiological system activity at different degree, during dosed and maximal exercises the total effects can highlight the properties of central and peripheral mechanisms and reveal significant synergies between the central and peripheral cardiovascular processes.

Research aim was to determine the peculiarities of central and peripheral indices of cardiovascular system while performing dosed and maximal exercise tests.

Research methods. Two groups took part in the study - sportsmen-sprinters (16) and sportsmen - endurance group (11). The participants of the study performed Roufier exercise and $30 \mathrm{~s}$ maximal jump test with maximal efforts. The 12-leads ECG was registered continuously and the changes of heart rate (HR), JT interval and ratio JT/ RR were analysed. Near-infrared spectroscopy was employed for continuous registration of the changes in oxygen saturation $\left(\mathrm{StO}_{2}\right)$ and arterial blood flow.

Research results. The results obtained during the study showed increasingly changing ECG indices while performing exercise load in both athlete groups but there was no statistically significant difference between groups while performing maximal exercise, thus oxygen saturation and arterial blood flow was statistically significantly faster and decreased more in sprint athlete group.

Discussion and conclusion. Dosed and maximal exercise test indicated the peculiarities of cardiovascular function of athletes, although more differences between individual peculiarities of athletes can be revealed while performing a dosed exercise test and still more differences - while the maximal exercise tests are performed and during the recovery after exercising.
\end{abstract}

Keywords: dosed and maximal exercise test, cardiovascular system, endurance, sprint.

\section{INTRODUCTION}

$\mathrm{T}$ The body's functional state and functional fitness and a number of studies of regulatory mechanisms of functional systems are carried out by monitoring the reactions induced by functional tests or exercises. The functional state of the body can be estimated by changes in functional parameters (Wilkinson et al., 2009) during the dosed maximal exercise tests. Muscle activity is the factor which may change cardiovascular system activity at the highest degree and most rapidly. Physical load resulting changes in body function are not the changes of the state in an individual body system, but it is a whole set of complex and interrelated processes (Biggiero, 2001). In such chain of processes concatenations of cardiovascular, the central and peripheral regulatory mechanisms play an important role (Delp, 1999; Jones, Pole, 2007). Due to increasing metabolic needs in the body many cardiovascular processes begin almost at the same time in order to ensure a sufficient supply of oxygen (Hughson, 2007). Changes in cardiovascular function shift in 
accordance with the alteration of physical load to the maximum. No regulatory mechanism of blood flow work in isolation, it interacts with a whole system or performs as a part of regulatory system; hence it is important to perceive these interactions occurring during exercise.

Since varying types of physical workloads activate the processes of different physiological systems at different degrees, during dosed and maximal exercises the total effects can highlight the properties of central and peripheral mechanisms and reveal significant synergies between the central and peripheral cardiovascular parameters.

\section{RESEARCH METHODS}

The participants of the study were 27 men -16 sprint (age $-18-24$ years., BMI $-21.4 \pm 1.8 \mathrm{~kg} / \mathrm{m}^{2}$ ) and 11 endurance runners (age - 21-26 years, BMI $-20.2 \pm 0.42 \pm 1.5 \mathrm{~kg} / \mathrm{m}^{2}$ ). The study involved non-professional sportsmen engaged in the chosen sports not less than for two years. All participants performed two tests: Roufier exercise (30 squats per $45 \mathrm{~s}$ ) and $30 \mathrm{~s}$ vertical jump test with maximal efforts. Using computerized ECG analysis system "Kaunas-load" during the Roufier exercise test and two min of recovery after the load, the 12 lead ECG was recorded. We analysed heart rate (HR), JT interval and JT/RR ratio. Oxygen saturation $\left(\mathrm{StO}_{2}\right)$ and blood flow in muscle ( $m$. vastus lateralis) was recorded by near-infrared spectroscopy method.

Statistical analysis of the data. Analysis was conducted using statistical package SPSS for Windows 17.0. Standard statistical methods were used to calculate means and standard deviations $( \pm \mathrm{SD})$. A one-way analysis of variance (ANOVA) was used to establish the differences between the measurements. The difference in mean was regarded as statistically significant when error probability with respect to criteria was $\mathrm{p}<0.05$.

\section{RESEARCH RESULTS}

Figure 1 presents the dynamics of HR during Roufier exercise and $30 \mathrm{~s}$ maximal jump tests. Before Roufier HR was statistically significantly higher in sprint group $87.5 \pm 4.0$ beats $/ \mathrm{min}$, in endurance group $-84.4 \pm 4.8$ beat $/ \mathrm{min}(\mathrm{p}<0.05)$. After Roufier exercise test in sprint group HR increased to $129.4 \pm 5.9 \mathrm{beat} / \mathrm{min}$, in endurance group $-126.4 \pm 4.9$ beat $/ \mathrm{min}(\mathrm{p}>0.05)$. During the recovery process after two minutes of Roufier test workload the HR changes were statistically significant in both groups: in sprint group they recovered till $87.7 \pm 4.4$ beat $/ \mathrm{min}$, in endurance group $-81.2 \pm 5.6$ beat $/ \mathrm{min}(\mathrm{p}<0.05)$. The HR recovery after $30 \mathrm{~s}$ vertical jump test was established in sprint group $-154.6 \pm 6.4$ beat $/ \mathrm{min}$, in endurance group $-149.7 \pm 6.5 \mathrm{beat} / \mathrm{min}$, and it was not statistically significant, $\mathrm{p}>0.05$.

Comparing JT interval changes during Roufier exercise test in both groups (Figure 2), we established that before the test it was statistically significantly higher in the endurance group $(0.27 \pm 0.01 \mathrm{~s}$; sprint group $-0.25 \pm 0.01 \mathrm{~s} ; \mathrm{p}<0.05)$, but after Roufier exercise this index was simlar in both groups $-0.22 \pm 0.01 \mathrm{~s}$, and no statistically significant differences were found $(p>0.05)$.

Comparing values of JT/RR ratio changes we established that in sprint group they were higher - during Roufier exercise test $0.46 \pm 0.01$, in endurance group $-0.44 \pm 0.01$, after $30 \mathrm{~s}$ vertical
Figure 1. Dynamics of HR during dosed and maximal exercise test

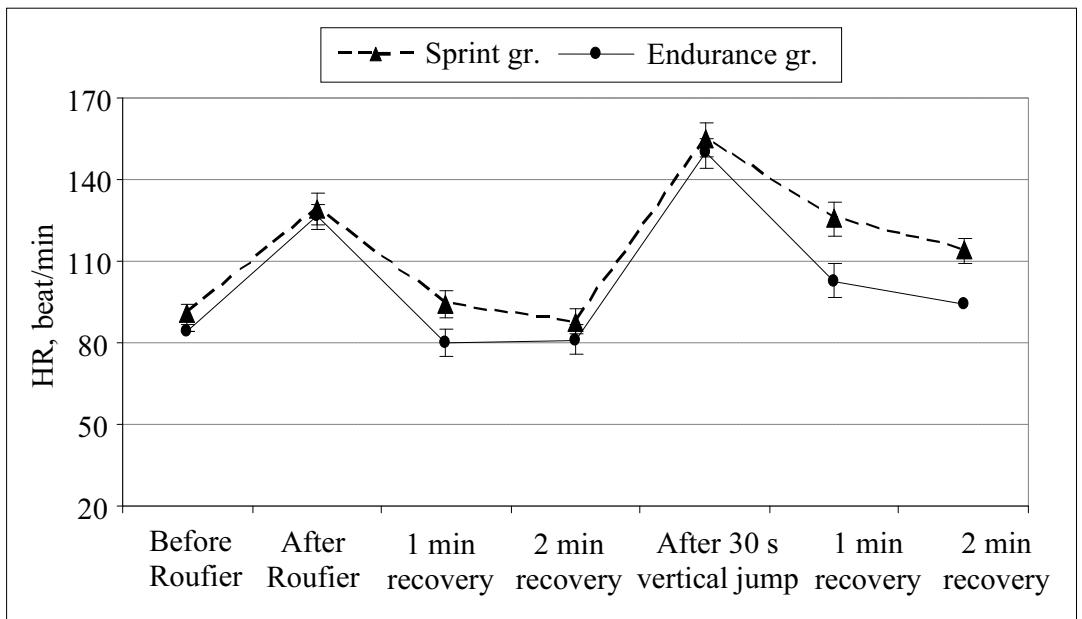




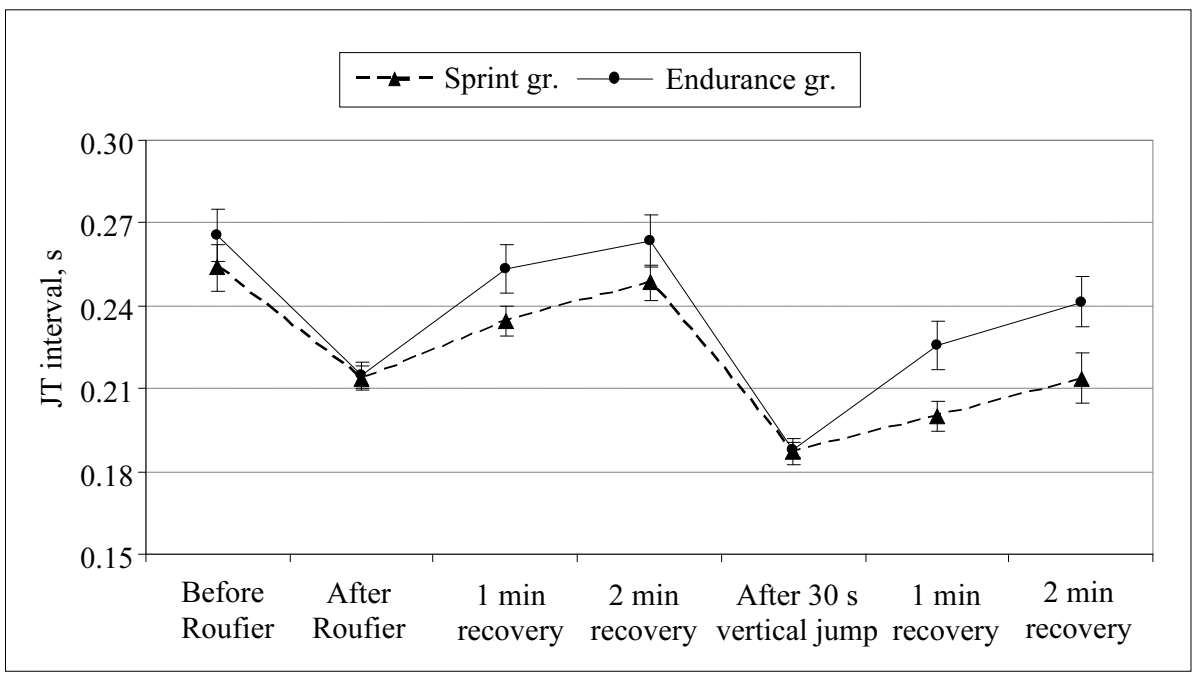

Figure 2. Dynamics of JT interval during dosed and maximal exercise test

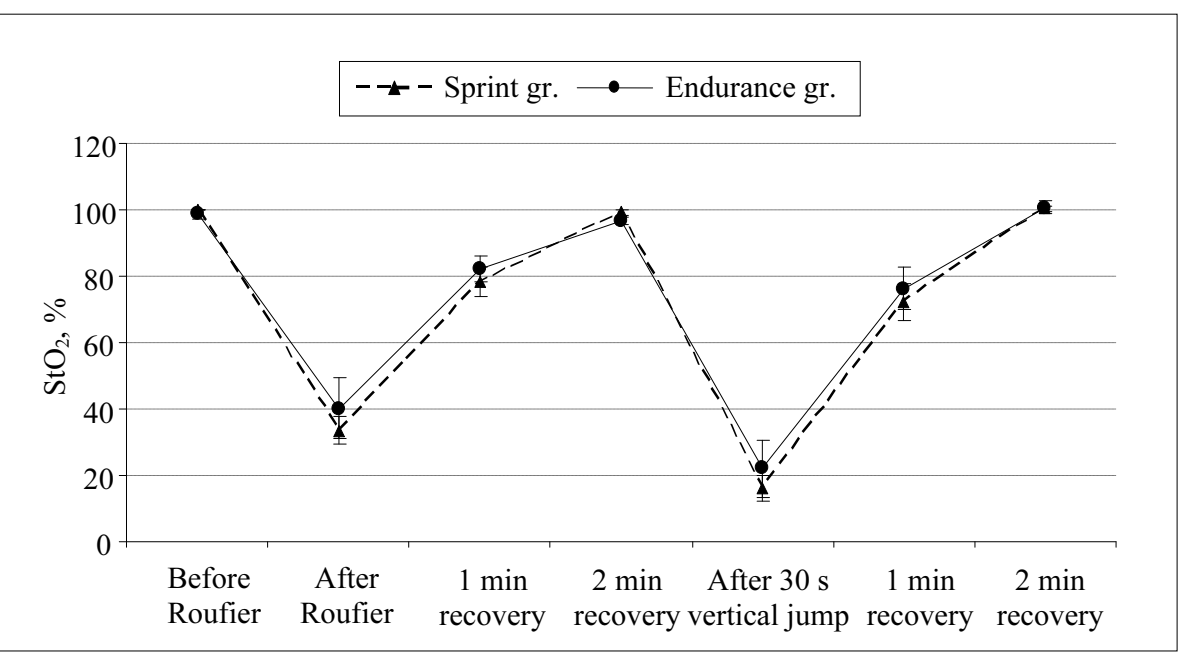

Figure 3. Dynamics of $\mathrm{StO}_{2}$ during dosed and maximal exercise test

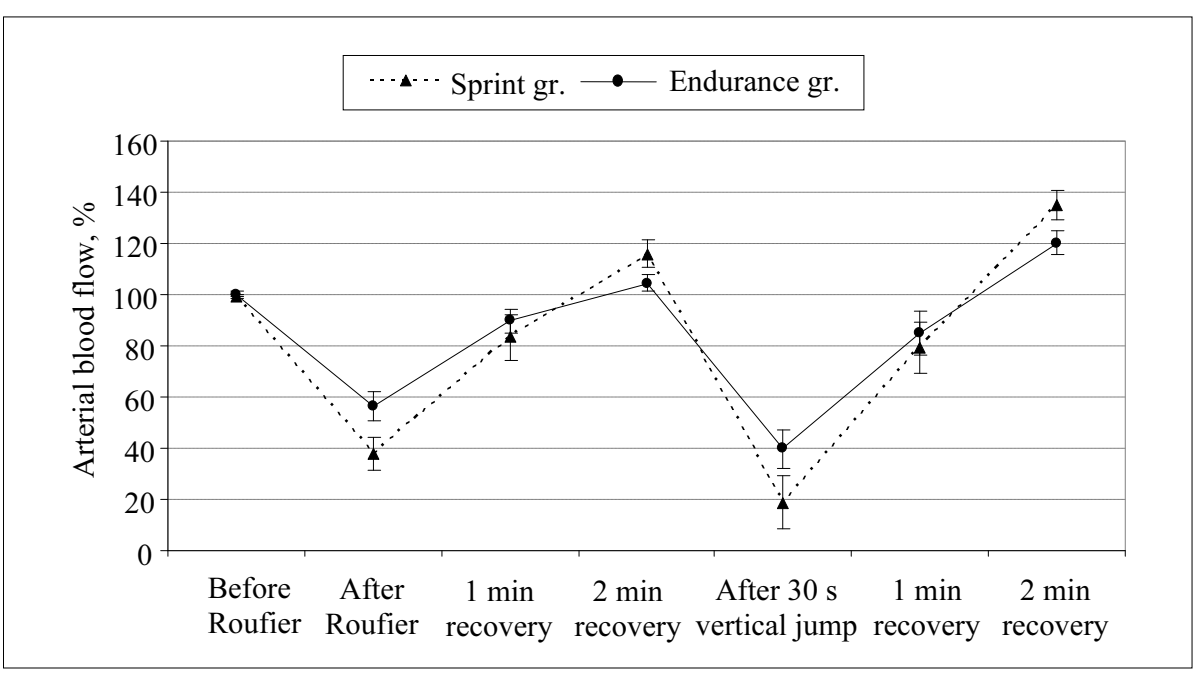

Figure 4. Dynamics of arterial blood flow during dosed and maximal exercise test 
jump test JT/RR values were similar in both groups $-0.47 \pm 0.01(\mathrm{p}>0.05)$.

Figure 3 presents $\mathrm{StO}_{2}$ dynamics. We assessed statistically significant $(\mathrm{p}<0.05)$ oxygen saturation decrease to $72.9 \pm 8.9 \%$ in endurance athlete group, in sprint group $\mathrm{StO}_{2}$ from base line decreased to $76.1 \pm 4.4 \%$ after Roufier exercise test. During the first minute after Roufier exercise test $\mathrm{StO}_{2}$ recovered $(\mathrm{p}<0.05)$. After $30 \mathrm{~s}$ vertical jump test $\mathrm{StO}_{2}$ decreased to $94.7 \pm 1.9 \%$ in sprint group, in endurance group $-84.7 \pm 8.8 \%(\mathrm{p}<0.05)$.

After Roufier exercise test the arterial blood flow intensity decreased to $56.7 \pm 8.6 \%$ in endurance group, in sprint group $-73.4 \pm 8.3 \%$ (Figure 4). During the first minute after Roufier exercise test in sprint group, the arterial blood flow intensity increased more then in endurance group $(17.6 \pm 5.6 \%$ and $6.3 \pm 2.8 \%$ above baseline), this difference was statistically significant $(\mathrm{p}<0.05)$. After maximal exercise test, blood flow intensity decreased to $88.9 \pm 9.8 \%$ from baseline in sprint group, in endurance group $-70.5 \pm 7.7 \%$ from baseline $(\mathrm{p}<0.05)$.

\section{DISCUSSION}

While evaluating changes of the central and peripheral cardiovascular functional parameters induced by maximal and dosed exercise tests, we observed specific tendency: when the load was low while subject performed dosed exercise test, a lot of differences could be found between individuals adapted to a different type of physical load. After the analysis of cardiovascular parameters of speed and endurance athletes during Roufier test and 30 seconds of vertical jumps test, higher degree increase of registered central (ECG) and peripheral $\left(\mathrm{StO}_{2}\right.$ and arterial blood flow) system parametric changes were observed in the speed group. Differences in heart rate (HR) and its changes during dosed exercise tests should be considered as a result of different level of training and different kinds of exercise. Many studies have revealed that evolution of cardiovascular adaptation depends on the type of physical load and the length of training experience (Карпман, 1987). Athletes who develop aerobic endurance have the largest hearts (Fagard, 1997, 2006). The larger the heart (left ventricular end-diastolic diameter), the lower the maximum HR (Martinelli et al., 2005). Training designed to develop speed and power is not a very strong stimulus for the hypertrophy of myocardium even if it takes several hours per day (Haykowsky et al., 1998). So, these are the features of adaptation to physical loads, and they can explain the differences observed in the dynamics of HR and other estimated ECG's parameters, considering the difference between the groups adapted to speed and endurance loads.

In this study we also assessed the changes of ECG's ST-segment depression rate during physical load. ST-segment is a significant indicator of cardiovascular functionality and it is associated with the occurrence of myocardial functional ischemic processes, the assessment of its rate during physical load reflects cardiac functional fitness and its capacity (Enoka, Duchateau, 2008). As it has been pointed by many researchers, the capacity of cardiac reserve is very much dependent on the fulfilment of its oxygen demand, or how fast and whether it is a sufficient increase in oxygen delivery to the heart during physical load (Yazigi et al., 1998; Jernberg et al., 1999; Vainoras, 2002). Insufficient and substandard supply of myocardium with blood causes the lack of oxygen in the heart. It can occur because of very high physical or emotional tension. Adequate blood supply of the heart is a very important parameter of its working capacity (Žemaitytė, 1996; Yazigi et al., 1998). If coronary blood flow is insufficient during physical load, it changes the balance of metabolic processes and electrical potentials in myositis and consequently the changes are recorded in ECG as ST amplitude changes. Significantly higher values of this parameter were found in the speed group, but we have considered estimated ST-segment deviations as functional ischemic rather than pathological changes because after the termination of the load these effects disappeared quickly.

The aim of muscle blood flow is to provide muscles with blood, which is possible because of the interaction between the central and peripheral mechanisms regulating blood flow. While our investigation established that in the group of speed during Roufier test as well as during $30 \mathrm{~s}$ vertical jumps test, oxygen saturation and arterial blood flow decreased faster and at a higher level. Different response of periphery of speed and endurance groups to the tests could be conditioned by an unequal level of training experience, duration 
or type of physical load (Gocentas, Andziulis, 2004). It is known that endurance athletes have greater aerobic capacity than representatives of the speed-power group because of large-scale powerendurance load decrease in peripheral vascular tone regulatory options which are reimbursed by the central circulatory organ, the heart function an increase in systolic blood pressure (Poderys et al., 1999; Šilinskas, 2000).

\section{CONCLUSION AND PERSPECTIVES}

Dosed and maximal exercise tests indicate the peculiarities of cardiovascular function of athletes, more differences between individual peculiarities of athletes can be revealed while performing a dosed exercise test, and more differences while the maximal exercise tests are performed - during the recovery after exercising.

\section{REFERENCES}

Biggiero, L. (2001). Source of complexity in human systems: Nonlinear dynamics. Psychology and Life Sciences, 5 (1), 3-19.

Delp, M. D. (19990. Control of skeletal muscle perfusion at the onset of dynamic exercise. Medicine and Science in Sports and Exercise, 31 (7), 1011-1018.

Enoka, R. M., Duchateau, J. (2008). Muscle fatigue: What, why and how it influences muscle functuion. The Journal of Physiology, 586, 11-23.

Fagard, R. H. (2006). Exercise is good for your blood pressure: Effects of endurance training and resistance training. Clinical and Experimental Pharmacology Physiology, 33 (9), 853-856.

Fagard, R. H. (1997). Impact of different sports and training on cardiac structure and function. Clinical Cardiology, 15 (3), 397-412.

Gocentas, A., Andziulis, A. (2004). Krepšininku organizmo deguonies sunaudojimo pokyčiai atsigavimo metu. Medicina (Kaunas), 40 (6), 569-573.

Haykowsky, M. J., Chan, S., Bhambhami, Y. et al. (1998). Effects of combined endurance and strength training on left ventricular morphology in male and female rowers. Canadian Journal of Cariology, 14 (3), 387-391.

Hughson, R. L. (2007). Regulation of $\mathrm{VO}_{2}$ on kinetics by $\mathrm{O}_{2}$ delivery. In Oxygen Uptake Kinetics in Sport, Exercise and Medicine (pp. 185-211). London and New York: Routlege.

Jernberg, T., Lindahl, B., Wallentin, L. (1999). STsegment monitoring with continuous 12-lead ECG improves early risk stratification in patients with chest pain and ECG nondiagnostic of acute myocardial infarction. Journal American College of Cardiology, 1; 34 (5), 1413-1419.

Jones, A. M., Pole, D. C. (2007). Oxygen Uptake Kinetics in Sport, Exercise and Medicine. London and New York: Routlege.
Martinelli, F. S., Chacon-Mikahil, M. P., Martins, L. E. et al. (2005). Heart rate variability in athletes and nonathletes at rest and during head-up tilt. Brazilian Journal of Medical and Biological Research, 38 (4), 639-47.

Poderys, J., Vainoras, A., Šilinskas, V. et al. (1999). Širdies ir kraujagyslių funkcija bei dirbančių raumenų hemodinamikos ryšys fizinio krūvio metu. Lithuanian Journal of Cardiology, 6 (4), 832-836.

Šilinskas, V. (2000). Žmoniu, adaptuotu greitumo jëgos ir ištvermès fiziniams krūviams, blauzdos raumenu kraujotakos ypatumai: daktaro disertacija. Kaunas: LKKA.

Vainoras, A. (2002). Functional model of human organism reaction to load - evaluation of sportsman training effect. Ugdymas. Kūno kultūra. Sportas, 3, 88-93.

Yazigi, A. F., Richa, S., Gebara, F. et al. (1998). Prognostic importance of automated ST-segment monitoring after coronary artery bypass graft surgery. Acta Anaesthesiologica Scandinavica, 42 (5), 532-535.

Wilkinson, M., Leedale-Brown, D., Winter, E. M. (2009). Reproducibility of physiological and performance measures from a squash-specific fitness test. International Journal of Sports Physiology and Performance, 4 (1), 41-53.

Žemaitytè, D. (1996). Širdies ritmo ir kraujotakos reguliavimo mechanizmu principai. Kardiovaskuline sistema ir sportine veikla. Vilnius. P. 21-41, 50-53, 138-141.

Карпман, В. Л. (1987). Спортивная медицина. Москва: Физкультура и спорт. 


\title{
CENTRINIŲ BEI PERIFERINIŲ ŠIRDIES IR KRAUJAGYSLIŲ SISTEMOS RODIKLIŲ KAITOS YPATYBĖS ATLIEKANT DOZUOTO IR MAKSIMALAUS KRŪVIO MËGINIUS
}

\author{
Birutė Zacharienė, Jonas Poderys, Eugenijus Trinkūnas, Alfonsas Buliuolis \\ Lietuvos kūno kultūros akademija, Kaunas, Lietuva
}

\begin{abstract}
SANTRAUKA
Tyrimo pagrindimas ir hipotezè. Ivairaus pobūdžio fiziniai krūviai skirtingai aktyvina organizmo fiziologines sistemas, todèl atliekant dozuotus ar maksimalius fizinius krūvius jie gali atskleisti centrinių ir periferinių mechanizmu sąsajas, t. y. esmines sinergijas tarp ŠKS centrinių ir periferinių rodiklių.

Tikslas - nustatyti centrinių bei periferinių širdies ir kraujagyslių sistemos (ŠKS) rodiklių kaitos ypatybes atliekant dozuoto ir maksimalaus krūvio mėginius.

Metodai. Buvo tiriama 16 sprinto ir 11 ištvermès bègikų. Visi tiriamieji atliko fizinio krūvio ir $30 \mathrm{~s}$ trukmès vertikalių šuoliu mėginius. Tyrimo metu buvo nenutrūkstamai registruojama 12 EKG standartinių derivacijų. Analizuoti šie rodikliai: širdies susitraukimo dažnis (ك̌SD), JT intervalo trukmė ir JT/RR intervalų santykis. Deguonies isotinimas $\left(\mathrm{StO}_{2}\right)$ ir kraujotakos kitimas buvo registruojami nenutrūkstamai neinvaziniu artimosios infraraudonosios spektroskopijos būdu.

Rezultatai. Atliekant maksimalaus krūvio mėginius, registruojamų centriniu (EKG) rodiklių pokyčiai tarp grupių statistiškai reikšmingai nesiskyrè, o periferinių sistemu $\left(\mathrm{StO}_{2}\right.$ ir arterinės kraujotakos) pokyčiai buvo didesni greitumo grupeje.

Aptarimas ir išvada. Dozuoto ir maksimalaus fizinio krūvio mėginiai parodo sportuojančiujų širdies ir kraujagyslių funkcinio parengtumo ypatybes, tačiau daugiau skirtumų galima nustatyti atliekant dozuoto krūvio mėgini, o stebint atsigavimo po krūvio ypatybes - po maksimalaus krūvio mėginio.
\end{abstract}

Raktažodžiai: dozuotas ir maksimalus fizinis krūvis, širdies ir kraujagyslių sistema, ištvermè, sprintas.

Gauta 2012 m. birželio 21 d.

Received on June 21, 2012

Priimta $2012 \mathrm{~m}$. rugsèjo $7 \mathrm{~d}$

Corresponding author Birutė Zacharienè

Accepted on September 7, 2012

Lithuanian Academy of Physical Education

Sporto str. 6, LT-44221 Kaunas

Lithuania

Tel+37061221220

E-mail biruseb@gmail.com 